\title{
Cigarette and water pipe smoking patterns among hospitalized men with a cardiovascular disease diagnosis
}

\author{
Rami Azmi Elshatarat ${ }^{1,2}$, Marguerite M. Engler ${ }^{1,3}$, Nancy A. Stotts ${ }^{1}$, Erika Sivarajan Froelicher ${ }^{1,4,5}$ \\ 1. Department of Physiological Nursing, School of Nursing, University of California, San Francisco, California, USA. \\ 2. Department of Adult Health Nursing, School of Nursing, Al-Ghad International Colleges for Applied Medical Sciences, \\ Al-Madinah Al-Munawarah, Kingdom of Saudi Arabia. 3. National Institutes of Health, Bethesda, Maryland, USA. 4. Health \\ Sciences, Sifa University, Izmir, Turkey. 5. Department of Epidemiology and Biostatistics, School of Medicine, University \\ of California, San Francisco, California, USA.
}

Correspondence: Rami Azmi Elshatarat. Address: Department of Adult Health Nursing, School of Nursing, Al-Ghad International Colleges for Applied Medical Sciences, Al-Madinah Al-Munawarah, Kingdom of Saudi Arabia.

Email: elshatrat@hotmail.com

Received: J une 28,2014

DOI : 10.5430/jnep.v4n10p118
Accepted: August 12, 2014

Online Published: August 24, 2014

\section{Abstract}

Background: Smoking is the most preventable cause of death worldwide. Despite the high prevalence of smoking and cardiovascular disease (CVD) in Jordan, little is known about smoking in hospitalized patients with CVD.

Objectives: To describe the perceptions, history, and patterns about cigarette and water pipe smoking in hospitalized patients with CVD in Jordan.

Methods: Across-sectional design and convenience sampling method were used to recruit a total of 112 men who were hospitalized with CVD. A structured interview was used to obtain the data.

Results: The subjects were men, and the majorities were middle-aged, married, highly educated, and employed. About $12 \%$ of the subject had major depression. Most of the men (91\%) were daily cigarette smokers. The majority of subjects reported that smoking was allowed inside their home (89.3\%) and in the presence of children (64\%). About $43 \%$ of subjects smoked $>20$ cigarettes per day and $63 \%$ of subjects smoked their first cigarette within 30 minutes after waking. Most of the water pipe smokers (66.7\%) preferred to smoke their water pipe while socializing with friends. More cigarette smokers (77\%) than water pipe smokers (40\%) believed that smoking is addictive. A logistic regression analysis showed that men with less than high school education (OR: 4.18, 95\% CI: 1.16, 15.13), and who smoked more than 20 cigarettes per day (OR: 7.34, 95\% CI: 2.53, 21.33) were inclined to smoke their first cigarette within 30 minutes after awakening in the morning (high nicotine dependence); suggesting that they were addicted.

Conclusion: Smoking is highly prevalent among hospitalized patients with CVD. Strategies are needed to screen these patients for smoking status. Concerted efforts are needed to implement tailored smoking cessation programs with education, counseling, and pharmacological support.

\section{Keywords}

Smoking, Water pipe, Cardiovascular disease, Predictors of nicotine dependence, Jordan 


\section{I ntroduction}

Cardiovascular disease (CVD) is the leading cause of death in the United States ${ }^{[1]}$ and accounts for more than $40 \%$ of all deaths in Jordan ${ }^{[2,3]}$. A cardiovascular event increases the risk for a subsequent event ${ }^{[4,5]}$ and tobacco use is a major modifiable risk factor for CVD, the leading cause of death globally ${ }^{[6]}$.

The smoking rate in Jordan is particularly high. Nearly $47 \%$ of men and $6 \%$ of women smoke ${ }^{[7]}$; about half of the patients hospitalized with acute coronary syndrome had previously smoked ${ }^{[8]}$. Cigarettes are the most frequently used tobacco delivery system. The water pipe or "Argeelah" also known "Narghile" is highly prevalent in Middle Eastern countries, and is also gaining popularity in the United States and Europe ${ }^{[9-12]}$. Like cigarette smoking, water pipe smoking is associated with nicotine dependence and adverse health consequences including cancer, CVD, respiratory disease, and low infant birth weight ${ }^{[10,13,14]}$.

In Arabic countries water pipe smoking is an important social activity that is part of cultural traditions and ceremonies such as weddings and funerals ${ }^{[15]}$. In Jordan, water pipes are smoked both in the home and cafes/restaurants, exposing children and older adults to the deleterious effects of smoke. Water pipe smokers have less frequent exposure (1-4 sessions per day) than cigarette smokers but they get more intense exposure per session as their duration of smoking lasts 15 and 90 minutes. Water pipe smokers inhale similar or higher concentrations of carbon monoxide (CO), nicotine, tar, and heavy metals as with cigarettes ${ }^{[10,11,14]}$.

Water pipe smokers believe that water pipes are less harmful and addictive than cigarettes ${ }^{[16-18]}$ and that they could easily quit smoking anytime they wish, but have no intentions of quitting ${ }^{[17-20]}$. Prior studies show knowledge deficits, and misconceptions about the harms of second-hand smoking ${ }^{[14,21-23]}$, health hazards and nicotine dependence among water pipes users ${ }^{[14,19,21-23]}$ and health care providers ${ }^{[17,20]}$.

There is a reciprocal link between tobacco use and depression. Depression is more common in smokers than non-smokers, and smoking is more common in those with depression when compared to those without depressions ${ }^{[24,25]}$. Depressed smokers are also less likely to quit smoking when compared to non-depressed smokers ${ }^{[26]}$. Importantly, major depression is associated with CVD, especially during hospitalization after a myocardial infarction ${ }^{[24,25,27]}$. In addition, the joint presence of major depression and tobacco use increases the morbidity and mortality in persons with CVD ${ }^{[24,25]}$. Furthermore, those with CVD are more likely to have recurrent cardiac events and die than those without depression ${ }^{[24,28-30]}$. Smoking and depression are risk factors of CVD, particularly among hospitalized patients, and the presence of both increases morbidity and mortality rates in patients with $\mathrm{CVD}^{[24,25,27]}$.

Anti-smoking legislation initiated in Jordan in 1977 prohibits smoking in public places, tobacco advertising, and the sale of tobacco to minors. Violation of these laws can result in both a fine and imprisonment for a week to a month ${ }^{[31-33]}$. While designed to promote a tobacco-free community and protect individuals from exposure to second hand smoke ${ }^{[31-33]}$, the enforcement of these regulations has been limited ${ }^{[33]}$.

Despite legislation to stop smoking, there are no smoking cessation programs available for the general public, including patients with CVD. Research is needed to determine the attitudes and beliefs about smoking as well as predictors of nicotine dependence as the basis for developing smoking cessation programs. In addition, more data are needed about depression in persons with CVD in Jordan.

\section{Research objectives}

The objectives of this study were to: (1) identify the demographical and clinical profile of hospitalized smokers with CVD, including their cardiovascular risk factors and degree of depression; (2) describe their smoking history and perceptions about smoking in public places; (3) identify predictors of nicotine dependence; and (4) explore the pattern of smoking in the home, the work place, and in the presence of children. 


\section{Design and methods}

\subsection{Study design}

This cross-sectional study was approved by the institutional review board at the University of California, San Francisco and two private hospitals in Amman, Jordan where the study was conducted. All participants gave written informed consent.

\subsection{Setting and sample}

A convenience sample of 112 men hospitalized with a diagnosis of CVD including heart failure, arrhythmia and who were admitted to the hospital for interventional cardiology or cardiac surgery were included in the study. Additional inclusion criteria were: age $>18$ years, daily smoking, mentally alert and oriented, and a medically stable condition.

\subsection{Data collection procedure}

The principal investigator (PI $[\mathrm{RE}]$ ) reviewed each patient's medical records to determine study eligibility. Data was collected by the PI using structured questionnaires completed through personal interviews.

\subsection{Measurements}

The subjects' medical records were reviewed to obtain demographic, clinical, CVD risk factors, and body mass index data.

The Global Adult Tobacco Survey (GATS). Core Questionnaire with Optional Questions ${ }^{[34]}$ was used to assess subjects' history, perceptions and pattern about cigarette and water pipe smoking, and polices in the home and public places. The GATS questionnaire was developed by the Centers for Disease Control and Prevention (CDC) and World Health Organization (WHO) and is a nationally representative cross-sectional household tobacco survey. It has been used to assess tobacco use in 14 low and middle income countries, the United Kingdom, and the United States ${ }^{[34,35] .}$

The Narghile-Water pipe Users Survey was used to determine history, patterns, and perceptions about water pipe smoking. This survey was adopted from a previous study ${ }^{[36]}$.

Depression Screener. The PHQ-2 ${ }^{[37]}$ and PHQ-9 ${ }^{[38]}$ were used to identify the subject's depressive symptoms. The PHQ-2 consists of two screening questions "Over the past 2 weeks, how often have you been bothered by any of the following problems? 1) Little interest or pleasure in doing things, and 2) feeling down, depressed, or hopeless." The PHQ-2 is a valid instrument with sensitivity (62.0-82.9) and specificity (90.0-95.4) established ${ }^{[37]}$. Subjects that rated $\geq 1$ to either question completed all 9 PHQ items (PHQ-9) ${ }^{[38]}$. Depression severity for the PHQ-9 ranges from 1 to 27 and is divided into five categories ${ }^{[38]}$ with established sensitivity $(0.80)$ and specificity $(0.92)^{[39]}$.

The time to first cigarette in the morning (TTFC). Nicotine dependence was measured with the single item: "how soon after you awake do you smoke your first cigarette?" ${ }^{[40]}$ The TTFC is significantly correlated with biomarkers of nicotine exposure, including cotinine levels ${ }^{[41-43]}$. The TTFC is established with significant reliability ${ }^{[47,48]}$ and predictive validity ${ }^{[44-46]}$. The responses to the TTFC question are coded to $(0:>30$ minutes and $1: \leq 30$ minutes $)$. A quicker time to first cigarette after awakening indicated higher nicotine dependence ${ }^{[42-44,49]}$. Arabic versions of the Narghile-Water pipe Users Survey ${ }^{[36]}$, the PHQ-2 ${ }^{[37]}$ and PHQ-9 ${ }^{[38]}$ were used. English version of GATS Core Questionnaire and TTFC questionnaire were translated to Arabic and then back-translated to English using Beaton et al guidelines ${ }^{[50]}$.

\subsection{Data analysis}

Statistical analysis was performed using the Statistical Package for the Social Sciences (SPSS, version 17). Descriptive data analysis included percentages, frequencies, mean, and standard deviations $( \pm \mathrm{SD})$. Multiple logistic regression was used to identify potential associations between age, education, marital status, depression, age started smoking cigarettes, and the number of cigarettes smoked per day and nicotine dependence. The significance level was pre-set at 0.05 . 


\section{Results}

Of the 126 eligible subjects, 112 men participated; the response rate was $89 \%$. Eleven declined to participate and three did not complete the interview. Most subjects were middle-aged [mean age $52.5( \pm 9.7)$ years], married $(75.0 \%)$, employed (63\%), and had completed high school or higher levels of education (68\%) (see Table 1).

Table 1. Demographic and clinical data $(\mathrm{n}=112)$

\begin{tabular}{|c|c|}
\hline & Mean (SD*) \\
\hline Age (years) & $52.5( \pm 9.7)$ \\
\hline Weight $(\mathrm{kg})$ & $77.4( \pm 10.6)$ \\
\hline Height (cm) & $168.4( \pm 6.4)$ \\
\hline Body Mass Index (BMI) kg/cm² & $27.24 \pm(3.0)$ \\
\hline Demographics & $\%$ (n) \\
\hline \multicolumn{2}{|l|}{ Marital status } \\
\hline Single & $5.4(6)$ \\
\hline Married & $75.0(84)$ \\
\hline Divorced & $2.7(3)$ \\
\hline Widowed & $17.0(19)$ \\
\hline \multicolumn{2}{|l|}{ Level of education } \\
\hline No formal schooling & $2.7(3)$ \\
\hline Primary school & $11.6(13)$ \\
\hline Secondary school & $17.9(20)$ \\
\hline High school & $30.4(34)$ \\
\hline College/university & $34.8(39)$ \\
\hline Post-graduate degree & $2.7(3)$ \\
\hline \multicolumn{2}{|l|}{ Work status } \\
\hline Government employee & $17.9(20)$ \\
\hline Non-government employee & $29.5(33)$ \\
\hline Self-employed & $16.1(18)$ \\
\hline Retired & $21.4(24)$ \\
\hline Unemployed & $15.2(17)$ \\
\hline \multicolumn{2}{|l|}{ Monthly family income (JD*) } \\
\hline$<400$ & $39.3(38)$ \\
\hline $401-800$ & $47.3(53)$ \\
\hline$>800$ & $13.4(15)$ \\
\hline \multicolumn{2}{|l|}{ Clinical data } \\
\hline \multicolumn{2}{|l|}{ Unit where interviewed } \\
\hline Intensive and Coronary care unit (ICU \& CCU) & $66.0(74)$ \\
\hline Cardiac catheterization recovery unit & $4.5(5)$ \\
\hline Medical/surgical ward & $29.5(33)$ \\
\hline \multicolumn{2}{|l|}{ Diagnosis on admission } \\
\hline Coronary artery diseases & $68.8(77)$ \\
\hline Congestive heart failure & $8.9(10)$ \\
\hline Arrhythmia & $8.0(9)$ \\
\hline Others $\ddagger$ & $14.4(16)$ \\
\hline \multicolumn{2}{|l|}{ Cardiovascular Risk Factors } \\
\hline Hypertension & $55.4(62)$ \\
\hline CVD family history & $56.3(63)$ \\
\hline Diabetes mellitus & $39.3(44)$ \\
\hline Hyperlipidemia & $30.4(34)$ \\
\hline \multicolumn{2}{|l|}{ Number of CVD risk factor(s) ** } \\
\hline No CVD risk factor & $16.1(18)$ \\
\hline One CVD risk factor & $27.7(31)$ \\
\hline Two CVD risk factors & $25.0(28)$ \\
\hline Three CVD risk factors & $21.4(24)$ \\
\hline Four CVD risk factors & $9.8(11)$ \\
\hline \multicolumn{2}{|l|}{ Body Mass Index (BMI) $\mathrm{kg} / \mathrm{cm}^{2}$} \\
\hline Normal (18.5 - 24.9) & $19.6(22)$ \\
\hline Overweight ( $25.0-29.9)$ & $64.3(72)$ \\
\hline Obese ( $30.0-39.9)$ & $16.1(18)$ \\
\hline
\end{tabular}

* SD: Standard deviation. $\dagger \mathrm{JD}=$ Jordanian dinar $(1 \mathrm{JD}=\$ 1.40) .+$ Cardiomyopathy, aortic aneurysm, coronary heart disease, valvular heart disease, endocarditis.

**Number of CVD risk factor(s) other than smoking, and including family history of CVD, hypertension, diabetes mellitus, or hyperlipidemia. 


\subsection{Cardiovascular risk factors}

Hypertension, family history of CVD, and obesity were the most common cardiovascular risk factors. Only $16 \%$ of subjects had no CVD risk factors other than smoking. About $28 \%$ of men had one of the following CVD risk factors including family history of CVD, hypertension, diabetes mellitus, or hyperlipidemia. Twenty-five percent of subjects had two cardiovascular risk factors, and 10\% of them had four CVD risk factors (see Table 1). The majority of subjects had a body mass index (BMI) greater than $25 \mathrm{~kg} / \mathrm{m}^{2}$, indicating they were overweight or obese (see Table 1).

\subsection{Smoking history, patterns, and perceptions}

Most men were daily cigarette smokers and had smoked an average of 36 years. On average, the subjects reported that they smoked about 25 cigarettes per day, $43 \%$ reported that they smoked $>20$ cigarettes per day and approximately $37 \%$ of subjects smoked the first cigarette in less than 30 minutes after waking (see Table 2). On average, subjects started cigarette smoking when they were about 17 years old. Only one third reported that warning labels on cigarette packages led them to think about quitting. About half of cigarette smokers (48.6\%) believed that all cigarettes were equally harmful. Approximately $57 \%$ of water pipe smokers believed that cigarettes were more harmful than water pipes.

With regard to smoking history, most water pipe smokers began smoking in their mid-twenties. The majority of water pipe smokers reported that they started to use water pipes with their friends. About two-thirds preferred to smoke water pipes with friends in their homes or in the cafés or restaurants, and shared the same water pipe with others. Three-quarters of water pipe smokers reported that they increased smoking during the holidays or when they felt stressed. Approximately $67 \%$ believed that they could quit water pipe smoking any time.

Not all cigarette smokers (77\%) and even fewer water pipe smokers (40\%) were aware of the addictive properties of tobacco. Water pipe smokers believed that cigarettes were more addictive than water pipes (see Table 2).

\subsection{Predictors of nicotine dependence}

A multiple regression model was tested using the statistically significant associated variables in previous studies ${ }^{[4,46]}$. This model included age, education, marital status, age of first cigarette, and number of cigarettes smoked per day. The dependent variable was nicotine dependence measured by time to first cigarette after awakening. Table 3 shows that level of education (< high school) (OR: 4.18,95\% CI: 1.16, 15.13) and smoking > 20 cigarettes per day (OR: 7.34, 95\% CI: 2.53, 21.33) were significantly related to high levels of nicotine dependence.

\subsection{Depression}

The Depression Screening Scores in response to PHQ-2, showed about 18.8\% of men had "been bothered by little interest or pleasure in doing things", and 19.6\% "felt down, depressed, or hopeless" during the past 2 weeks. The PHQ-2 (cut point $\geq 3$ ) classified $11.6 \%$ of subjects as having major depression (see Table 4). The mean PHQ-9 score was $6.8( \pm 3.2)$, indicating that most subjects (59.5\%) had responses equivalent to mild depression.

\subsection{Smoking history and attempts to quit smoking prior to hospitalization}

About $70 \%$ of all the subjects reported that they had visited their doctor or other health care provider in the past 12 months and the majority was asked if they smoked and were advised to quit smoking by their health care provider (see Table 5).

More than one-third of cigarette smokers (40.2\%) reported trying to stop cigarette smoking at least once during the past 12 months. The mean quit time for the last attempt to quit cigarette smoking was 21.9 days $( \pm 25.2)$. Only $19 \%$ of water pipe smokers quit smoking at least once during the past 12 months and the mean duration of the last water pipe quit attempt was 37 days ( \pm 46$)$ (see Table 5). 
Table 2. Smoking history, patterns, and perceptions

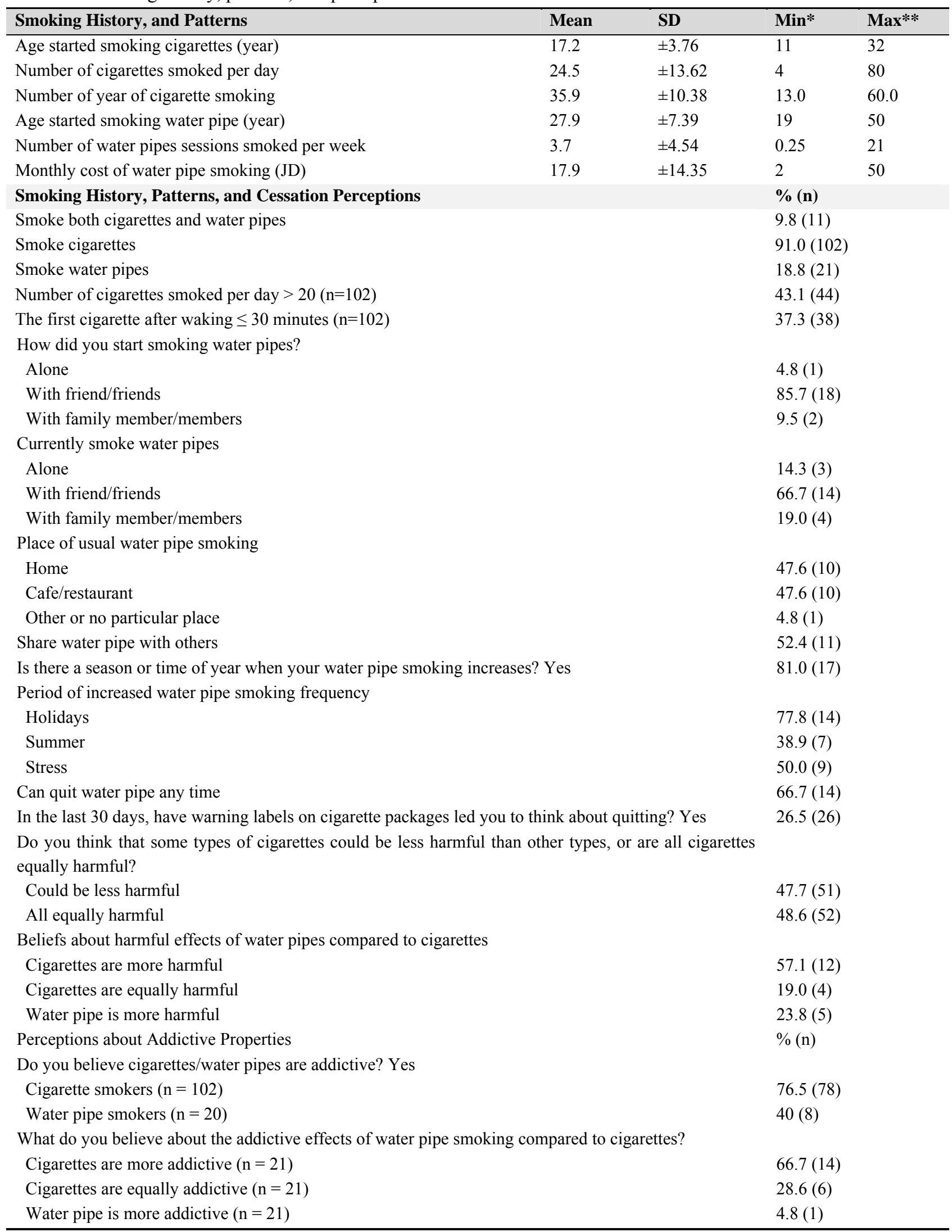

** Minimum. ${ }^{\dagger}$ Maximum 
Table 3. Multiple logistic regression to predict the nicotine dependence

\begin{tabular}{llll}
\hline Outcome variable: the time to first cigarette after awakening $^{\text {\& }}$ & OR & $\mathbf{9 5 \%}^{\text {CI }}$ & $\boldsymbol{p}_{\text {-value }}$ \\
\hline Age $(\geq 52$ years) & 1.07 & $0.36,3.18$ & .91 \\
Education (< high school) & 4.18 & $1.16,15.13$ & $.03^{*}$ \\
Marital status(married) & 2.60 & $0.77,8.80$ & .13 \\
Depression (PHQ-2 $\geq 3$ ) & 1.01 & $0.23,4.41$ & .99 \\
Age started smoking cigarettes ( $\leq 17$ years) & 1.50 & $0.55,4.06$ & .43 \\
Number of cigarettes smoked per day $>20)$ & 7.34 & $2.53,21.33$ & $<.05^{*}$ \\
\hline
\end{tabular}

Note. OR, Odds ratio; CI, confidence interval; ${ }^{\S}$ Outcome variable was coded as 0 : Low dependence ( $>30$ minutes); 1: High dependence $(\leq 30$ minutes). Comparisons: age ( $<52$ years); education ( $\geq$ high school); marital status(not married); depression (PHQ-2 $<3$ ); age started smoking cigarettes $\left(>17\right.$ years); number of cigarettes smoked per day $(\leq 20) ;{ }^{*} \mathrm{P}$ value is significant $(<0.05)$.

Table 4. Patient health questionnaire and depression severity

\begin{tabular}{|c|c|c|}
\hline \multicolumn{2}{|l|}{ Depression Screening Score } & $\%(n)$ \\
\hline \multicolumn{3}{|c|}{ Over the past 2 weeks, have you been bothered by any of the following problems: (response was "yes" and rated } \\
\hline \multicolumn{3}{|l|}{$\geq 1)$} \\
\hline 1) Little interest or pleasure in doing things & & $18.8(21$ \\
\hline 2) Feeling down, depressed, or hopeless & & $19.6(22$ \\
\hline Brief Patient Health Questionnaire (PHQ-2) total score $\geq 3(\mathrm{n}=112)$ & & $11.6(13$ \\
\hline Patient Health Questionnaire (PHQ-9) (n=33) & Mean & $( \pm \mathrm{SD})$ \\
\hline PHQ-9 total score $(n=33)$ & 6.8 & $( \pm 3.2)$ \\
\hline Depression Severity & PHQ-9 total score & $\%(n)$ \\
\hline Minimal depression & $1-4$ & $24.2(8)$ \\
\hline Mild depression & $5-9$ & $57.6(19)$ \\
\hline Moderate depression & $10-14$ & $15.2(5)$ \\
\hline Moderately severe depression & $15-19$ & $3.0(1)$ \\
\hline Severe depression & $20-27$ & $0(0)$ \\
\hline
\end{tabular}

Table 5. Smoking assessment before hospitalization and history of quitting attempts

\begin{tabular}{ll}
\hline Smoking Assessment before Hospitalization & \% (n) \\
\hline Visited a doctor or other health care provider in the past 12 months & $69.6(78)$ \\
Number of doctor or health care provider visits in the past 12 months & $53.8(42)$ \\
1 or 2 & $34.6(27)$ \\
3 to 5 & $11.5(9)$ \\
6 or more & $83.3(65)$ \\
$\begin{array}{l}\text { During any visit to a doctor or health care provider in the past } 12 \text { months, were you asked if you smoke } \\
\text { tobacco? Yes ( }=78)\end{array}$ & $87.7(57)$ \\
$\begin{array}{l}\text { During any visit to a doctor or health care provider in the past } 12 \text { months, were you advised to quit smoking } \\
\text { tobacco? Yes ( } \mathrm{n}=65)\end{array}$ & $40.2(41)$ \\
History of Quitting Attempts & $19.0(4)$ \\
During the past 12 months, have you tried to stop cigarette smoking? Yes & Mean ( \pm SD) \\
During the past 12 months, have you tried to stop water pipe smoking? Yes & $21.9( \pm 25.21)$ \\
How long was the last period of quitting cigarette smoking? (days) & $37.0( \pm 46.03)$ \\
How long was the last period of quitting water pipe smoking? (days) & \\
\hline
\end{tabular}




\subsection{Smoking customs}

With regard to smoking customs, 2 to 11 persons reportedly live in the subject's home and are also exposed to smoking. About half of the subjects (49\%) reported that they were the only male smoker in their home and nearly $40 \%$ reported that they had more than one male smoker in their home (including the subject). Only $7 \%$ reported that there was a female smoker in their household (see Table 6). Some subjects reported a maximum of 6 children reside in the household who would be exposed to smoking.

Table 6. Smoking customs at home and perceptions about indoor smoking policies $(\mathrm{n}=112)$

\begin{tabular}{|c|c|c|}
\hline Smoking Customs at Home & Min* & Max** \\
\hline Number of persons who live in the subject's household (including the subject) & 2 & 11 \\
\hline \multicolumn{3}{|l|}{ Number of children in subject's household } \\
\hline Boys & 0 & 6 \\
\hline Girls & 0 & 6 \\
\hline \multirow[t]{2}{*}{ Number of household members who were current smokers (including the subject) } & No. of smokers & $\%(n)$ \\
\hline & 1 & $48.6(54)$ \\
\hline \multirow[t]{2}{*}{ Male } & 2 & $38.7(43)$ \\
\hline & $3-5$ & $12.7(14)$ \\
\hline Female & 1 & $7.2(8)$ \\
\hline Rules about Smoking & $\%(n)$ & \\
\hline \multicolumn{3}{|l|}{ Rules about smoking inside the home } \\
\hline Smoking inside the home is allowed & $89.3(100)$ & \\
\hline Smoking in every room inside the home is allowed & $40.2(45)$ & \\
\hline Smoking in the presence of children is allowed & $64.0(71)$ & \\
\hline \multicolumn{3}{|l|}{ Rules about smoking inside workplaces } \\
\hline \multicolumn{3}{|l|}{ Work indoors or outdoors } \\
\hline Indoors & $69.4(50)$ & \\
\hline Outdoors & $11.1(8)$ & \\
\hline Both & $19.4(14)$ & \\
\hline Smoking policy at work indicates smoking is not allowed in any indoor areas & $19.4(13)$ & \\
\hline Men smoking indoor at work & $76.6(49)$ & \\
\hline Other people smoking indoors at work & $82.9(92)$ & \\
\hline \multicolumn{3}{|l|}{ Support the law that prohibits smoking inside these indoor areas } \\
\hline Hospitals & $93.1(95)$ & \\
\hline Workplaces & $68.6(70)$ & \\
\hline Restaurants & $61.8(63)$ & \\
\hline Public transportation vehicles & $86.3(88)$ & \\
\hline Schools & $98.0(100)$ & \\
\hline Universities & $86.3(88)$ & \\
\hline Places of worship & $99.0(101)$ & \\
\hline
\end{tabular}

* Minimum. ** Maximum.

\subsection{Perceptions about indoor smoking policies}

Smoking was permitted inside the majority (89.3\%) of subjects' homes but less than half allowed it in every room. More than half (64\%) of those who allowed smoking inside their homes indicated that smoking inside was permitted in the presence of children (see Table 6). 
Nearly three-quarters of the subjects worked indoors, $81 \%$ of whom reported that smoking was allowed everywhere. Most of the subjects who worked indoors reported that they had smoked at work and noticed other people also smoke indoors at work during the past 30 days (see Table 6).

The majority of the subjects indicated that they supported the law that prohibits smoking inside places of worship (99\%), schools $(98 \%)$, or hospitals $(93.1 \%)$. About two thirds of subjects supported the law that prohibits smoking inside workplaces $(68.6 \%)$ or restaurants $(61.8 \%)$ (see Table 6$)$.

\section{Discussion}

This study provides important data about the characteristics of Jordanian men who smoke tobacco and were hospitalized with CVD. Importantly, the majority of subjects were married and employed, had a high school education or higher, and started smoking in adolescence. CVD risk factors were prevalent in this patient population and the majority of subjects experienced depression. Predictors of nicotine dependence included an educational level less than high school and smoking more than 20 cigarettes daily.

In addition to smoking, other prevalent CVD risk factors included family history of CVD, hypertension, diabetes mellitus, and hyperlipidemia. These findings are consistent with a previous investigation in a similar sample ${ }^{[51]}$. The presence of several CVD risk factors in these subjects multiplies the risk of death ${ }^{[2,3]}$. In addition, the prevalence of overweight/obese men in this study confirms previous findings ${ }^{[2,53]}$ and indicates that obesity is a major emerging risk factor for CVD as well as other health problems in Jordanians ${ }^{[52,53]}$. Therefore, CVD risk factor modification is critical for this population. The establishment of cardiac rehabilitation programs should be emphasized, as such programs are equipped to offer comprehensive risk reduction strategies using education, counseling and behavioral interventions.

Understanding an individual's pattern of smoking is very important in planning smoking cessation educational efforts and interventions. Compared to other populations, most subjects in this study started smoking cigarettes as adolescents, earlier than American ${ }^{[54,55]}$ or Korean patients hospitalized with CVD ${ }^{[46]}$. Reasons for starting cigarette smoking before 18 years of age included motivation by smokers in their household and community, lack of knowledge about the health consequences of smoking, cigarette accessibility, and the cultural belief that smoking is associated with attaining "real man"status ${ }^{[20,56,57]}$. Health educational programs about the hazards of second-hand smoke are also needed based on the number of family members exposed, as well as stricter enforcement of tobacco control laws ${ }^{[31-33]}$.

Water pipe smoking is perceived as safe and without health consequences; it also is viewed as an attractive social activity ${ }^{[22]}$. These findings are similar to those from American ${ }^{[18]}$ and British ${ }^{[58]}$ studies where the majority of subjects started water pipe smoking before the age of 21 years, with more than one of their friends at home, and they usually shared the same water pipe with others. Because it was started as a social activity and at a young age, water pipe smokers may have been unaware of the health hazards of secondhand smoke or potential for addiction ${ }^{[18,58]}$.

In addition, most subjects in this study thought cigarette smoking was more harmful than water pipe smoking. Our findings are contrary to Maziak and colleagues ${ }^{[22]}$ who reported that the majority of subjects believed that water pipes are more harmful than cigarettes. However, several other studies in various countries are in agreement with our results ${ }^{[22,59-61]}$. Knowledge deficits about the harmful effects of water pipe smoking might be associated with the notion that filtering smoke through warm water creates a less toxic inhalation without harm. Importantly, water pipe smoking requires more force to pull air through the water to burn the tobacco in water pipes, which leads to a deeper inhalation of the water pipe smoke and toxins into the lungs.

In this study, the majority of water pipe smokers believed that cigarettes were more addictive than water pipes and believed they could quit smoking water pipes at any time. These results are consistent with other previous studies ${ }^{[18,61]}$. It 
should be noted however, that the evidence suggests that cigarettes and other forms of tobacco are powerful "addictive drugs" ${ }^{[62]}$. The nicotine concentration in the water pipes is similar or higher than cigarettes ${ }^{[14]}$. Water pipe users are exposed to nicotine concentrations that are the equivalent of 100-200 cigarettes per session ${ }^{[15,63]}$. Clearly education about the hazards and addictive qualities of water pipe smoking in the community is a priority. At risk younger populations including children and adolescents need to be targeted in educational efforts along with adults. An emphasis on second-hand smoke, and the addictive properties of both cigarettes and water pipes should be part of educational programs.

Our study showed that high school educational levels or lower and smoking more than 20 cigarettes per day are predictors of nicotine dependence. Others have reported predictors of nicotine dependence in various populations but not patients with CVD from Jordan. In Korean patients with CVD, Sohn and colleagues ${ }^{[46]}$ found that predictors of nicotine dependence include educational level, age of first cigarette and number of cigarettes smoked per day. In Americans, Schnoll and colleagues ${ }^{[45]}$ found that significant predictors of nicotine dependence included being single, elderly, presence of CVD and a psychiatric illness. Our study and those in other populations have revealed important factors related to nicotine dependence. Based on the differences in predictors across populations, it may be that cultural factors affect nicotine addiction predictors; further investigations are needed to explore this possibility.

It was particularly interesting to find that that more than one in 10 subjects in our study experienced major depression. This has been studied and is reportedly less than in other populations e.g. pregnant women, patients with cancer or diabetes in Jordan ${ }^{[64-66]}$, Americans with CVD ${ }^{[54,67]}$, and Korean patients with CVD ${ }^{[46]}$. However, it may not be identified or acknowledged in Jordanian men. It is also not clear whether depression leads to smoking or smoking leads to depression. Existing data indicate that lack of patient acceptance of the diagnosis of depression is one of the major barriers to identification and treatment of depression in Jordanians ${ }^{[68]}$. This is an area that requires further investigation.

It also should be noted that major depression is not routinely screened or assessed in patients with CVD in the health care system in Jordan. Education is needed for health care providers, particularly physicians, about identification, diagnosis and treatment of major depression. Providing referral of patients with major depression to specialized medical care (counseling and pharmacological treatment) is recommended to treat depressed patients ${ }^{[68]}$.

While the majority of subjects in this study had visited their health care provider in the last year and were advised to quit smoking, subjects indicated that no smoking cessation interventions or educational materials were provided. Most hospitals and clinics in Jordan lack structured tools to assess smoking history and behavior and patients are not provided education to reduce risk factors for CVD by health care providers. Evidence also suggests that health care providers (nurses and physicians) who smoke (more than $60 \%$ ) are less likely to advise patients to quit smoking when compared with non-smoking professionals ${ }^{[20]}$. Therefore, providing smoking cessation training programs for health care providers is urgently needed to enhance their skills in assessing, advising and assisting their patients to quit smoking ${ }^{[17,69]}$. The absence of educational efforts to prevent smoking may be related to academic preparation of health care providers. Typical nursing and medical schools in Jordan do not address smoking cessation education ${ }^{[17]}$ in their programs. Content on tobacco dependence and treatment needs to be added to the curricula of all Jordanian health science schools ${ }^{[17]}$.

The results of our study support the need for major public health campaigns designed to reduce smoking. By making people aware of the hazards of cigarette and water pipe smoking and increased risk of CVD, a national approach may result in substantial reductions in smoking and the associated health care costs. Moreover, at risk populations including children and adolescents are a priority for any educational efforts.

Specific strategies for smoking cessation in patients with CVD are needed to enhance successful quit smoking attempts, decrease the health hazards of tobacco use, and increase the short- and long-term health benefits of smoking cessation. Key elements of smoking cessation programs include behavioral counseling, pharmacological therapy, and reduction of the number of cigarettes smoked per day prior to quitting smoking ${ }^{[70]}$. One approach that has successfully achieved long-term 
smoking cessation and relapse prevention is the combination of counseling and pharmacological therapy ${ }^{[70]}$. As part of the health care team, nurses have a major role in assessing patients for smoking and in promoting smoking cessation strategies ${ }^{[20,69,71]}$.

\section{Study strengths and limitations}

The results of this study provide important information as the basis for future intervention and research studies. A strength of the study was the use of standardized instruments which lends credibility to the findings. While the use of non-probability sampling may limit the generalizability of the results, there is little evidence that the characteristics of patients admitted to the hospitals across Jordan differ. Only men were studied, so data cannot be generalized to women hospitalized with CVD. In addition, a cross-sectional study design was used thus causality cannot be assumed. Intervention studies are needed to enhance smoking cessation in Jordanians.

Despite the limitations of this study, the information obtained from hospitalized smokers with CVD is important. The results of this study yielded useful baseline information that can be used to establish effective smoking cessation programs in Jordan and hopefully be applicable to other Arab countries.

\section{Conclusion}

To improve smoking cessation rates, public health campaigns are needed. A broad public health educational approach is needed to increase national awareness of the health hazards and negative effects of all types of smoking. Comprehensive health education that includes all types of media e.g., television, radio, internet, newspapers and billboards is needed to disseminate information about the detrimental effects of smoking and second-hand smoke. Adults need to be aware of the harmful effects of smoking in homes around children and older persons. Such a campaign could readily target children and adolescents at an age when they are likely to start smoking and be a part of their curricula in schools.

In addition, smoking regulations need to be enforced in the community. A focus needs to be on not smoking in public places, indoor work places, and hospitals in Jordan. Institutions as well as individuals must be responsible for enforcing existing laws.

Medical advice for smoking cessation and tailored self-help educational materials about smoking are needed. Brochures, pamphlets, videotapes, and audiotapes about the hazards of smoking on health, addictive proprieties of water pipe and cigarette smoking, benefits of quitting smoking, and the strategies to quit smoking need to be provided to help patients quit smoking ${ }^{[70]}$.

Given our findings, health care providers need to assess, advise, and assist patients in smoking cessation, or refer them to appropriate counseling and smoking cessation programs. To provide effective education about nicotine dependence and tobacco use, health care providers need to be educated so they have adequate knowledge about the health hazards of smoking (cigarettes and water pipes) and smoking cessations strategies.

Further studies are needed to identify the barriers for hospitalized patients with CVD to quit smoking, and the perceptions about nicotine withdrawal symptoms for those who willing to quit smoking in the future needs to be determined.

\section{Conflict of interest}

The opinions expressed in this article are the authors' own and do not reflect the view of the National Institutes of Health, the U.S. Department of Health and Human Services, or the United States Government.

\section{Acknowledgment}

The authors would like to thank all the subjects who participated in this study. The authors gratefully acknowledge Dr. Dianne Christopherson for her advice and valuable suggestions during the planning of this study, and Dr. Steven Paul for 
his statistical consultation. Our thanks are also extended to the Directors of Nursing and Chief Medical Officers of the Specialty Hospital and the Al-Esra Hospital for allowing us to conduct this study in their settings. The authors would like to thank Dr. Todd Heatherton and his colleagues for permission to use The time to first cigarette in the morning (TTFC); Dr. TaghridAsfar and her colleagues for permission to use the Narghile-Water pipe Users Survey; and PHQ () Pfizer Inc. for permission to use the Patient Health Questionnaire-2 and Patient Health Questionnaire-9. This study was supported in part through the UCSF's: the Graduate Dean's Health Sciences Fellowship, an Osher Scholarship, a Century Club Fellowship, and the Graduate Student Research Award.

\section{References}

[1] Go AS MD, Roger VL, Benjamin EJ, Berry JD, Borden WB, et al. Heart disease and stroke statistics-2013 update: a report from the American Heart Association. Circulation. 2013; 127(1): e6-e245. PMid:23239837

http://dx.doi.org/10.1161/CIR.0b013e31828124ad

[2] Directorate of Information Studies and Research MoH, The Hashemite Kingdom of Jordan. Mortality in Jordan 2005. Amman (JO): Ministry of Health, The Hashemite Kingdom of Jordan. 2008.

[3] World Health Organization. Core Health Indicators. 2006. Available from: http://www.who.int/whosis/database/core/core_select_process.cfm

[4] Brown DW, Mokdad AH, Walke H, As'ad M, Al-Nsour M, Zindah M, et al. Projected burden of chronic, noncommunicable diseases in Jordan [letter]. Prev Chronic Dis 2009; 6(2): A78. Available from: http://www.cdc.gov/pcd/issues/2009/apr/08_0162.htm PMid:19289021

[5] Nsour M, Mahfoud Z, Kanaan MN, Balbeissi A. Prevalence and predictors of nonfatal myocardial infarction in Jordan. East Mediterr Health J. Jul-Aug 2008; 14(4): 818-830. PMid:19166165

[6] World Health Organization. WHO Report on the Global Tobacco Epidemic: The MPOWER package. 2008. Geneva, World Health Organization. Available at: www.who.int/tobacco/mpower

[7] World Bank. The World Bank Annual Report. 2010. Available at: http://siteresources.worldbank.org/EXTANNREP2010/Resources/WorldBank-AnnualReport2010.pdf.

[8] Hammoudeh A, Izraiq M, Hamdan H, et al, Is high-sensitive C-Reactive Protein an independent predictor of future cardiovascular events in Middle Eastern patients with acute coronary syndrome? European Heart Journal. 2007; 28 (suppl): 595.

[9] American Lung Association (ALA). An Emerging Deadly Trend: Waterpipe Tobacco Use, 2007. Available at $<$ http://www.lungusa2.org/embargo/slati/Trenda-lert_Waterpipes.pdf $>$

[10] American Lung Association. Hookah Smoking: A Growing Threat to Public Health. Smokefree Communities Project, 2011. Available at:

http://www.lung.org/stop-smoking/tobacco-control-advocacy/reports-resources/cessation-economic-benefits/reports/hookah-pol icy-brief.pdf

[11] Akl EA, Gunukula SK, Aleem S, et al. The prevalence of waterpipe tobacco smoking among the general and specific populations: a systematic review. BMC Public Health. 2011; 11:244. PMid:21504559 http://dx.doi.org/10.1186/1471-2458-11-244

[12] Maziak W. The global epidemic of waterpipe smoking. Addict Behav. 2011 Jan-Feb; 36(1-2): 1-5. PMid:20888700 http://dx.doi.org/10.1016/j.addbeh.2010.08.030

[13] Akl EA, Gaddam S, Gunukula SK, Honeine R, Jaoude PA, Irani J. The Effects of Waterpipe Tobacco Smoking on Health Outcomes: A Systematic Review. International Journal of Epidemiology. 2010; 39: 834-857. PMid:20207606 http://dx.doi.org/10.1093/ije/dyq002

[14] Knishkowy B, Amitai Y. Water-pipe (narghile) smoking: an emerging health risk behavior. Pediatrics. Jul 2005; 116(1): e113-119. PMid:15995011http://dx.doi.org/10.1542/peds.2004-2173

[15] World Health Organization. Tobacco use in shisha: Studies on waterpipe smoking in Egypt. 2006. eScholarship Repository: University of California. Available from: http://repositories.cdlib.org/tc/whotcp/SHISHA.

[16] Primack et al. Prevalence of and associations with waterpipe tobacco smoking among US university students. Ann Behav Med. 2008; 36: 81-86. PMid:18719977 http://dx.doi.org/10.1007/s12160-008-9047-6

[17] Shishani K, Nawafleh H, SivarajanFroelicher E. Jordanian nurses' and physicians' learning needs for promoting smoking cessation. ProgCardiovascNurs. Spring. 2008; 23(2): 79-83.

[18] Ward KD, Eissenberg T, Gray JN, Srinivas V, Wilson N, Maziak W. Characteristics of U.S. waterpipe users: a preliminary report. Nicotine Tob Res. Dec 2007; 9(12): 1339-1346. PMid:18058352 http://dx.doi.org/10.1080/14622200701705019

[19] Akl EA, Jawad M, Lam WY, Co CN, Obeid R, Irani J. Motives, beliefs and attitudes towards waterpipe tobacco smoking: a systematic review. Harm Reduct J.2013, 10(1):12. PMid:23816366 http://dx.doi.org/10.1186/1477-7517-10-12 
[20] Shishani, K., Nawafleh, H., Jarrah, H. \&SivarajanFroelicher, E. Smoking practices among Jordanian health professionals: A study about the impediments to tobacco control in Jordan. European Journal of Cardiovascular Nursing. 2011; 10(4): $221-227$. PMid:20826114 http://dx.doi.org/10.1016/j.ejcnurse.2010.08.001

[21] Hadidi, K., \& Mohammed, F. Nicotine content in tobacco used in hubble-bubble smoking. Saudi Medical Journal. 2004; 25(7): 912-917. PMid:15235699

[22] Maziak, W, Ward, K D, Soweid, R A, \&Eissenberg, T. Tobacco smoking using a water pipe: A re-emerging strain in a global epidemic. Tobacco Control. 2004; 13(4): 327-333. PMid:15564614 http://dx.doi.org/10.1136/tc.2004.008169

[23] Kofahi, M. M., \& Haddad, L. G. Perceptions of lung cancer and smoking among college students in Jordan. Journal of Transcultural Nursing. 2005; 16(3): 245-254. PMid:15980052 http://dx.doi.org/10.1177/1043659605274830

[24] Pozuelo L, Tesar G, Zhang J, Penn M, Franco K, Jiang W. Depression and heart disease: what do we know, and where are we headed? Cleve Clin J Med. Jan 2009; 76(1): 59-70. PMid:19122112 http://dx.doi.org/10.3949/ccjm.75a.08011

[25] Stafford L, Berk M, Jackson HJ. Tobacco smoking predicts depression and poorer quality of life in heart disease. BMC CardiovascDisord. 2013; 13:35. PMid:23705944 http://dx.doi.org/10.1186/1471-2261-13-35

[26] Ziedonis D, Hitsman B, Beckham JC, et al. Tobacco use and cessation in psychiatric disorders: National Institute of Mental Health report. NicTob Res. 2008; 10:1691-715. PMid:19023823 http://dx.doi.org/10.1080/14622200802443569

[27] Plante GE. Depression and cardiovascular disease: a reciprocal relationship. Metabolism. May 2005; 54(5 Suppl 1): $45-48$. PMid:15877313 http://dx.doi.org/10.1016/j.metabol.2005.01.013

[28] Blumenthal JA, Lett HS, Babyak MA, et al. Depression as a risk factor for mortality after coronary artery bypass surgery. Lancet. Aug 23 2003; 362(9384): 604-609. http://dx.doi.org/10.1016/S0140-6736(03)14190-6

[29] Carney RM, Rich MW, Freedland KE, et al. Major depressive disorder predicts cardiac events in patients with coronary artery disease. Psychosom Med. Nov-Dec 1988; 50(6): 627-633. PMid:2976950 http://dx.doi.org/10.1097/00006842-198811000-00009

[30] Sullivan MD, LaCroix AZ, Spertus JA, Hecht J, Russo J. Depression predicts revascularization procedures for 5 years after coronary angiography. Psychosom Med. Mar-Apr 2003; 65(2): 229-236. PMid:12651990 http://dx.doi.org/10.1097/01.PSY.0000058370.50240.AA

[31] Belbeisi A, Al Nsour M, Batieha A, Brown DW, Walke HT. A surveillance summary of smoking and review of tobacco control in Jordan. Global Health. 2009; 5(18). PMid:19951428

[32] Ma'ayeh. Jordan: Mass media campaign combating smoking requires serious commitment and not just words. Tobacco Control. WHO Tobacco Control Papers. 2003. Available from: http://repositories.cdlib.org/context/tc/article/1166/type/pdf/viewcontent

[33] Obaidi J. Policy analysis paper: protect public health from smoking dangers policy. The Middle East Journal of Nursing. June 2013; 7: (3).

[34] Centers for Disease Control and Prevention. Global Tobacco Surveillance System (GTSS), Global Adult Tobacco Survey (GATS): Core Questionnaire with Optional Questions. 2008. Available from: http://www.cdc.gov/tobacco/global/gats/questionnaire/pdfs/core_quesstionaire.pdf

[35] Giovino GA, Mirza SA, Samet JM, et al. Tobacco use in 3 billion individuals from 16 countries: an analysis of nationally representative cross-sectional household surveys. Lancet. Aug 2012; 380(9842): 668-679. http://dx.doi.org/10.1016/S0140-6736(12)61085-X

[36] Asfar, T., Ward, K. D., Eissenberg, T., \&Maziak, W. Comparison of patterns of use, beliefs, and attitudes related to waterpipe between beginning and established smokers. BMC Public Health. 2005; 5.

[37] Kroenke K, Spitzer RL, Williams JB. The Patient Health Questionnaire-2: validity of a two-item depression screener. Med Care. Nov 2003; 41(11): 1284-1292. PMid:14583691 http://dx.doi.org/10.1097/01.MLR.0000093487.78664.3C

[38] Kroenke K, Spitzer RL, Williams JB. The PHQ-9: validity of a brief depression severity measure. J Gen Intern Med. Sep 2001; 16(9): 606-613. PMid:11556941 http://dx.doi.org/10.1046/j.1525-1497.2001.016009606.x

[39] Gilbody S, Richards D, Brealey S, Hewitt C. Screening for depression in medical settings with the Patient Health Questionnaire (PHQ): a diagnostic meta-analysis. J Gen Intern Med. Nov 2007; 22(11): 1596-1602. PMid:17874169 http://dx.doi.org/10.1007/s11606-007-0333-y

[40] Heatherton TF, Kozlowski LT, Frecker RC, Fagerström KO. The Fagerström Test for Nicotine Dependence: a revision of the Fagerström Tolerance Questionnaire. Br J Addict 1991; 86: 1119-27. PMid:1932883 http://dx.doi.org/10.1111/j.1360-0443.1991.tb01879.x

[41] Branstetter SA, Muscat JE. Time to first cigarette and serum cotinine levels in adolescent smokers: National Health and Nutrition Examination Survey, 2007-2010. Nicotine Tob Res. Mar 2013; 15(3): 701-707. PMid:22990214 http://dx.doi.org/10.1093/ntr/nts189

[42] Heatherton, T., Kozlowski, L., Frecker, R., Rickert, W., Robinson, J. Measuring the heaviness of smoking: using self-reported time to the first cigarette of the day and number of cigarettes smoked per day. British Journal of Addiction.1989; 84(7): 791-799. PMid:2758152 http://dx.doi.org/10.1111/j.1360-0443.1989.tb03059.x 
[43] Muscat JE, Stellman SD, Caraballo RS, Richie JP, Jr. Time to first cigarette after waking predicts cotinine levels. Cancer Epidemiol Biomarkers Prev. Dec 2009; 18(12): 3415-3420. PMid:19959690 http://dx.doi.org/10.1158/1055-9965.EPI-09-0737

[44] Baker TB, Piper ME, McCarthy DE, et al. Time to first cigarette in the morning as an index of ability to quit smoking: implications for nicotine dependence. Nicotine Tob Res. Nov 2007; 9Suppl 4: S555-570. Mid:18067032 http://dx.doi.org/10.1080/14622200701673480

[45] Schnoll RA, Goren A, Annunziata K, Suaya JA. The prevalence, predictors and associated health outcomes of high nicotine dependence using three measures among US smokers. Addiction. Nov 2013; 108(11): 1989-2000. PMid:23795712 http://dx.doi.org/10.1111/add.12285

[46] Sohn M, Benowitz N, Stotts N, et al. Smoking behavior in men hospitalized with cardiovascular disease in Korea: a cross-sectional descriptive study. Heart Lung. Sep-Oct 2008; 37(5): 366-379. PMid:18790337 http://dx.doi.org/10.1016/j.hrtlng.2007.11.001

[47] Etter JF, Perneger TV. Measurement of self reported active exposure to cigarette smoke. J Epidemiol Community Health. Sep 2001; 55(9): 674-680. PMid:11511648 http://dx.doi.org/10.1136/jech.55.9.674

[48] Pomerleau CS, Carton SM, Lutzke ML, Flessland KA, Pomerleau OF. Reliability of the Fagerstrom Tolerance Questionnaire and the Fagerstrom Test for Nicotine Dependence. Addict Behav. Jan-Feb 1994; 19(1): 33-39. http://dx.doi.org/10.1016/0306-4603(94)90049-3

[49] Fagerstrom K. Time to first cigarette; the best single indicator of tobacco dependence? Monaldi Arch Chest Dis. Jan-Mar 2003; 59(1): 91-94. PMid: 14533289

[50] Beaton DE, Bombardier C, Guillemin F, Ferraz MB. Guidelines for the process of cross-cultural adaptation of self-report measures. Spine. 2000; 25: 3186-3191 PMid:11124735 http://dx.doi.org/10.1097/00007632-200012150-00014

[51] Hammoudeh, A., Al-Tarawneh, H., Elharassis, et al. Prevalence of conventional risk factors in Jordanians with coronary heart disease: The Jordan Hyperlipidemia and Related Targets Study (JoHARTS). International Journal of Cardiology. 2006; 110: 179-183.

[52] World Health Organization. Country Cooperation Strategy for WHO and Jordan 2003 - 2007. Available from: http://www.who.int/countryfocus/cooperation_strategy/ccs_jor_en.pdf

[53] Khader Y, Batieha A, Ajlouni K, El Khateeb M, Ajlouni K. Obesity in Jordan: Prevalence, associated factors, comorbidities, and change in prevalence over ten years. MetabSyndrRelatDisord. 2008; 6: 113-20. PMid:18510436 http://dx.doi.org/10.1089/met.2007.0030

[54] Froelicher ES, Christopherson DJ, Miller NH, Martin K. Women's initiative for nonsmoking (WINS) IV: description of 277 women smokers hospitalized with cardiovascular disease. Heart Lung. Jan-Feb 2002; 31(1): 3-14. PMid:11805744 http://dx.doi.org/10.1067/mhl.2002.121247

[55] Smith PM, Reilly KR, Houston Miller N, DeBusk RF, Taylor CB. Application of a nurse-managed inpatient smoking cessation program. Nicotine TobRes. May 2002; 4(2): 211-222. PMid:12096707 http://dx.doi.org/10.1080/14622200210123590

[56] Haddad LG, Malak MZ. Smoking habits and attitudes towards smoking among university students in Jordan. Int J Nurs Stud. Nov 2002; 39(8): 793-802.http://dx.doi.org/10.1016/S0020-7489(02)00016-0

[57] Khader YS, Alsadi AA. Smoking habits among university students in Jordan: prevalence and associated factors. East Mediterr Health J. Jul-Aug 2008; 14(4): 897-904. PMid:19166173

[58] Jackson D, Aveyard P. Waterpipe smoking in students: prevalence, risk factors, symptoms of addiction, and smoke intake. Evidence from one British university. BMC Public Health. 2008; 8: 174. PMid:18498653 http://dx.doi.org/10.1186/1471-2458-8-174

[59] Ahmed B, Jacob P, 3rd, Allen F, Benowitz N. Attitudes and practices of hookah smokers in the San Francisco Bay Area. J Psychoactive Drugs. Apr-Jun; 43(2): 146-152.

[60] Roskin J, Aveyard P. Canadian and English students' beliefs about waterpipe smoking: a qualitative study. BMC Public Health. 2009;9:10. PMid:19134220 http://dx.doi.org/10.1186/1471-2458-9-10

[61] Smith-Simone S, Maziak W, Ward KD, Eissenberg T. Waterpipe tobacco smoking: knowledge, attitudes, beliefs, and behavior in two U.S. samples. Nicotine Tob Res. Feb 2008; 10(2): 393-398. PMid:18236304 http://dx.doi.org/10.1080/14622200701825023

[62] U.S. Department of Health and Human Services. The health consequences of smoking: Nicotine addiction, a report of the Surgeon General (DHHS Publication No. CDC 88-8406). Washington, DC: U.S. Government Printing Office. 1988.

[63] Neergaard J, Singh P, Job J, Montgomery S. Water pipe smoking and nicotine exposure: a review of the current evidence. Nicotine Tob Res. Oct 2007;9(10):987-994. PMid:17943617 http://dx.doi.org/10.1080/14622200701591591

[64] Abujilban SK, Abuidhail J, Al-Modallal H, Hamaideh S, Mosemli O. Predictors of Antenatal Depression Among Jordanian Pregnant Women in Their Third Trimester. Health Care Women Int. Aug 2013. PMid:24020729

[65] Al-Amer RM, Sobeh MM, Zayed AA, Al-Domi HA. Depression among adults with diabetes in Jordan: risk factors and relationship to blood sugar control. J Diabetes Complications. Jul-Aug 2011; 25(4): 247-252. PMid:21601482http://dx.doi.org/10.1016/j.jdiacomp.2011.03.001

Published by Sciedu Press 
[66] Mhaidat NM, Ai-Sweedan SA, Alzoubi KH, et al. Prevalence of depression among relatives of cancer patients in Jordan: a cross-sectional survey. Palliat Support Care. Mar 2011; 9(1): 25-29.

PMid:21352615http://dx.doi.org/10.1017/S1478951510000519

[67] Freedland KE, Rich MW, Skala JA, Carney RM, Davila-Roman VG, Jaffe AS. Prevalence of depression in hospitalized patients with congestive heart failure. Psychosom Med. Jan-Feb 2003; 65(1): 119-128.PMid:12554823 http://dx.doi.org/10.1097/01.PSY.0000038938.67401.85

[68] Nasir LS, Al-Qutob R. Barriers to the diagnosis and treatment of depression in Jordan. A nationwide qualitative study. J Am Board FamPract. Mar-Apr 2005; 18(2): 125-131. PMid:15798141 http://dx.doi.org/10.3122/jabfm.18.2.125

[69] Katz DA, Holman JE, Nugent AS, et al. The emergency department action in smoking cessation (EDASC) trial: impact on cessation outcomes. Nicotine Tob Res. Jun 2012; 15(6): 1032-1043. PMid:23125437 http://dx.doi.org/10.1093/ntr/nts219

[70] Fiore MC, Jaen CR., Baker TB, et al. Treating tobacco use and dependence: 2008 update. Rockville, MD: US Department of Health and Human Services, Public Health Service. 2008.

[71] Carson KV, Verbiest ME, Crone MR, et al. Training health professionals in smoking cessation. Cochrane Database Syst Rev. 2012.5:CD000214. 